\title{
SANITARY FACILITIES IN THE STATE OF MARANHÃO, BRAZIL
}

\author{
Raimunda Alves Silva ${ }^{1}$, Muryllo Santos Castro ${ }^{1}$, Veruska Costa de Jesus ${ }^{1}$, Mayanna Karlla Lima Costa \\ ${ }^{1}$ Federal University of Maranhão, UFMA. São Luís/MA, Brazil. ${ }^{3}$ Geografa. São Luís/MA, Brazil. \\ * Corresponding author: ray-234@hotmail.com
}

Received: Jun. 08, 2017 - Accepted: Aug. 16, 2017.

http://dx.doi.org/10.22615/2526-1746-jgm-2.2-6904

\begin{abstract}
Sanitary sewage consists of a necessary service for quality of life and promotion of public health. In Brazil, the index of households with adequate sanitary facilities is still low and irrelevant in relation to the demand in the country. This study study aimed to evaluate the amount of sanitary facilities in the households of the State of Maranhão. For this, we used data from the census of the Brazilian Institute of Geography and Statistics and from the Municipal Health Department, collected in 2000 and 2010. The analysis of data was performed by means of descriptive statistics and the generation of an isoline map using the Surfer 11 program. The results showed that in 2000, only 9 counties had more than 20,000 sanitary facilities. In 2010, this number increased to 12 municipalities. The data had lognormal distribution and high coefficient of variation. The state capital, São Luís, had a greater number of facilities and water supply. This stems from the greater contingent and distribution of GDP per capita. The counties of Nova Colinas and São Pedro dos Crentes had the lowest numbers of sanitary facilities. Sanitary sewage allows the adequate dispose of fecal waste and improves the quality of life of the population.
\end{abstract}

Key words: public health, basic sanitation, sanitary sewage, Maranhão State.

\section{INSTALAÇÕES SANITÁRIAS NO ESTADO DO MARANHÃO, BRASIL}

RESUMO: O esgotamento sanitário constitui serviços necessários a qualidade de vida e promoção de saúde pública. No Brasil, o índice de domicílios que apresentam instalações sanitárias adequadas ainda é baixo e irrelevante frente ao contingente demandado no país. O presente trabalho objetivou avaliar a quantidade de instalações sanitárias nos domicílios do Estado do Maranhão. Para isso utilizou de dados de domínio público do censo do Instituto Brasileiro de Geografia e Estatística e Secretaria Municipal de Saúde, coletados nos anos de 2000 e 2010. A análise dos dados foi realizada por meio de estatística descritiva e confecção de mapa isolinha usando programa Surfer 11. Os resultados evidenciaram que no ano 2000, apenas 9 municípios apresentaram número superior a 20.000 instalações sanitárias. Já no ano de 2010 esse número subiu para 12 municípios. Os dados obtiveram distribuição lognormal e coeficiente de variação alto. A capital do Estado São Luís deteve maior número de instalações e abastecimento de água, isso se deve ao maior contingente e distribuição do Produto Interno Bruto per capita (PIB per capita). Os municípios de Nova Colinas e São Pedro dos Crentes apresentaram-se com menores números de instalações sanitárias. O esgotamento sanitário possibilita o descarte adequado dos resíduos fecais e melhora a qualidade de vida da população.

Palavras-chave: saúde pública, saneamento básico, esgotamento sanitário, Estado do Maranhão.

\section{INTRODUCTION}


According to the World Health Organization (WHO), sanitation comprehends a series of socioeconomic actions aiming environmental health, controlling potentially harmful factors that cause or may cause harmful effects on physical, mental and social well-being of humans (GUIMARÃES et al, 2007).

Investing in sanitation is important for the economic development of a country, since the basic sanitation, besides providing access to treated water is a right of all. With relevant importance to public health, the quality of life of population and the environment (SCRIPTORE and JUNIOR, 2012). According to Law 11.445 / 2007, the sanitary sewage consists on one of the most important service of basic sanitation, encompassing activities, infrastructure and operational facilities of collection, transport, treatment and final disposal appropriate to the sanitary sewage, from residential facilities to their final release into the environment.

In this context, the sanitary facilities consist on a basic service to population, since they are constituted of collection and disposal of effluents from the use of water for domestic purposes. In numbers, about 2.4 billion people live without adequate sanitary facilities, consequently exposed to various contaminations (CHRISTOPHERSON, 2012).

Inadequate sanitary conditions directly influence the population health and quality of life. This is more common in underdeveloped countries, where infectious diseases continue to be the cause of morbidity and mortality. According to DANIEL et al. (2001), the prevalence of these diseases is a strong indicator of the fragility of public sanitation systems.
According to data from the IBGE (2015), in 2014, 1.8 million of permanent private households were registered without bathroom or sanitary in Brazil. Of this total, 634,000 were in urban and 1.2 million in rural areas. In this scenario, the State of Maranhão have the lowest numbers of households with sanitary facilities (IBGE, 2015). Therefore, the objective of this study was to know the quantity of sanitation facilities and to correlate with water supply, garbage collection, mortality and GDP per capita in the 217 counties of the State of Maranhão.

\section{MATERIAL AND METHODS}

The present work is a study conducted with secondary data of public domain, available on a broadly accessed basis, such as IBGE (Brazilian Institute of Geography and Statistics) and the Municipal Department of Health. It presents data referring to the quantity of sanitary facilities per household in the 217 counties in the State of Maranhão, according to demographic census of 2000 and 2010.

The State of Maranhão is one of the 27 provinces of Brazil, located West of the Northeast Region, whose capital is São Luis. It is limited to the North with Atlantic Ocean, to the East with State of Piauí, to the West with the State of Pará, and to the South and Southwest with State of Tocantins. It has an extensive coastline, comprising about $640 \mathrm{~km}$, very important for tourism of the State. The climate is classified tropical, with two defined seasons, one rainy and one dry, however, in the Northwest portion of the State the climate is considered equatorial, due to the influence of the Amazon forest. 
The data was first analyzed by means of descriptive statistics. It was calculated the measures of position (Number of states analyzed, sum, maximum, minimum, average, median), of dispersion (variance and standard deviation), of distribution (coefficient of variation, Coefficient of asymmetry and kurtosis) as well as the hypothesis of normality of data by the Kolmogorov-Smirnov normality test at $0.01 \%$ probability. All data were processed using Software Surfer version 13. The coefficient of variation (CV) was evaluated according to GOMES and GARCIA (2002), being considered as low CV <10\%; Medium $10<\mathrm{CV}<20 \%$; High 20\% <CV <30\% and very high $\mathrm{CV}>30 \%$.

The linear correlation between the counties and the number of sanitary facilities with the values of GDP was also analyzed. The program Surfer 13 was used to estimate the variability of the data, by which the isoline map of the data average for the years 2000 and 2010 was constructed.

\section{RESULTS AND DISCUSSION}

The data show a variation in the number of sanitary facilities in the 217 counties of Maranhão. In 2000, only seven counties had more than 20,000 sanitary facilities, comprising the counties of Bacabal $(21,173$ installations); Caxias (31,880 installations); Codó (25,078 installations); Imperatriz (34,534 installations); São José de Ribamar (23,430 installations); São Luís (202,231 installations) and Timon (29,399 facilities). In 2010 , the number of counties with more than 20,000 sanitary facilities increased to 12 , comprising the cities of Açailândia $(27,484$ facilities); Bacabal (26,246 facilities); Balsas
(21,247 facilities); Barra do Corda (21,663 facilities); Caxias (40,155 facilities); Codó $(29,541$ facilities); Imperatriz (68,561 facilities); Paço do Lumiar (27,114 facilities); Santa Inês (20,262 facilities); São José de Ribamar (42,562 facilities); São Luís (276,812 facilities); And Timon (40,487 facilities).

In 2000, from the 217 counties, nine had between 10,000 and 20,000 sanitary facilities and 200 had fewer than 10,000 facilities. The number of counties with sanitary facilities between 10,000 and 20,000 doubled in 2010, comprising 18 counties. 189 Counties were found with a number of sanitary facilities lower than 10,000 facilities. According to the United Nations (UN), at a General Assembly in July 2010, the right of a population to basic sanitation and potable water must be ensured. The World Health Organization (WHO) points out that the lack of basic sanitation is a major cause of public health problems and deaths worldwide. In 2004, this issue ranked the 11th position in the ranking of factors causing the risk of death (OMS, 2009, IBGE, 2004). This situation is most concerning in countries with the lower GDP per capita, where about 1.6 million deaths occurred in 2004.

São Luís was the county with highest number of sanitary facilities in the two years evaluated (Figure 2). Meanwhile, Nova Colinas had the lowest amount of facilities, only 718, followed by São Pedro dos Crentes, with 811, in2000. In the 2010 census, São Pedro dos Crentes had the lower amount of facilities, 1,105, followed by Nova Colinas, 1,118 (Figure 1). The WHO states that investments in basic sanitation reduce medical expenses and costs associated with controlling parasitic and infectious diseases (OMS, 2008). 
The services of sanitary sewage are necessary to avoid the contamination of water sources and minimize the spread of waterborne diseases in the population. According to MOURA et al. (2014), in 2010, only $10.52 \%$ of the country's population had adequate facilities for the disposal of fecal waste. According to these authors, $63.16 \%$ of the population had only rudimentary facilities such as fossa, ditch, discharge in rivers, lakes or sea. The remaining, $26.32 \%$, did not have a sewage. In the State of Maranhão, a rate of $57.84 \%$ of the population had a rudimentary sanitary facility in 2010.

The lack of basic sanitation results in numerous problems for the population, ranging from social, environmental and economic problems, constituting an important vector for the precariousness of health. As to human health, various diseases are caused by the absence of adequate sanitary facilities, such as typhoid fever, caused by poor hygiene and basic sanitation; Cholera, acute diarrhea; Hepatitis A and E; Toxoplasmosis (MOURA et al, 2016); Ascaridiasis (SILVA et al, 2010); Trichuriasis, ancylostomiasis, schistosomiasis (SAUCHA et al, 2015) and teniasis. The adequate sanitary prevent such diseases, allowing less contamination of the environment and water courses.

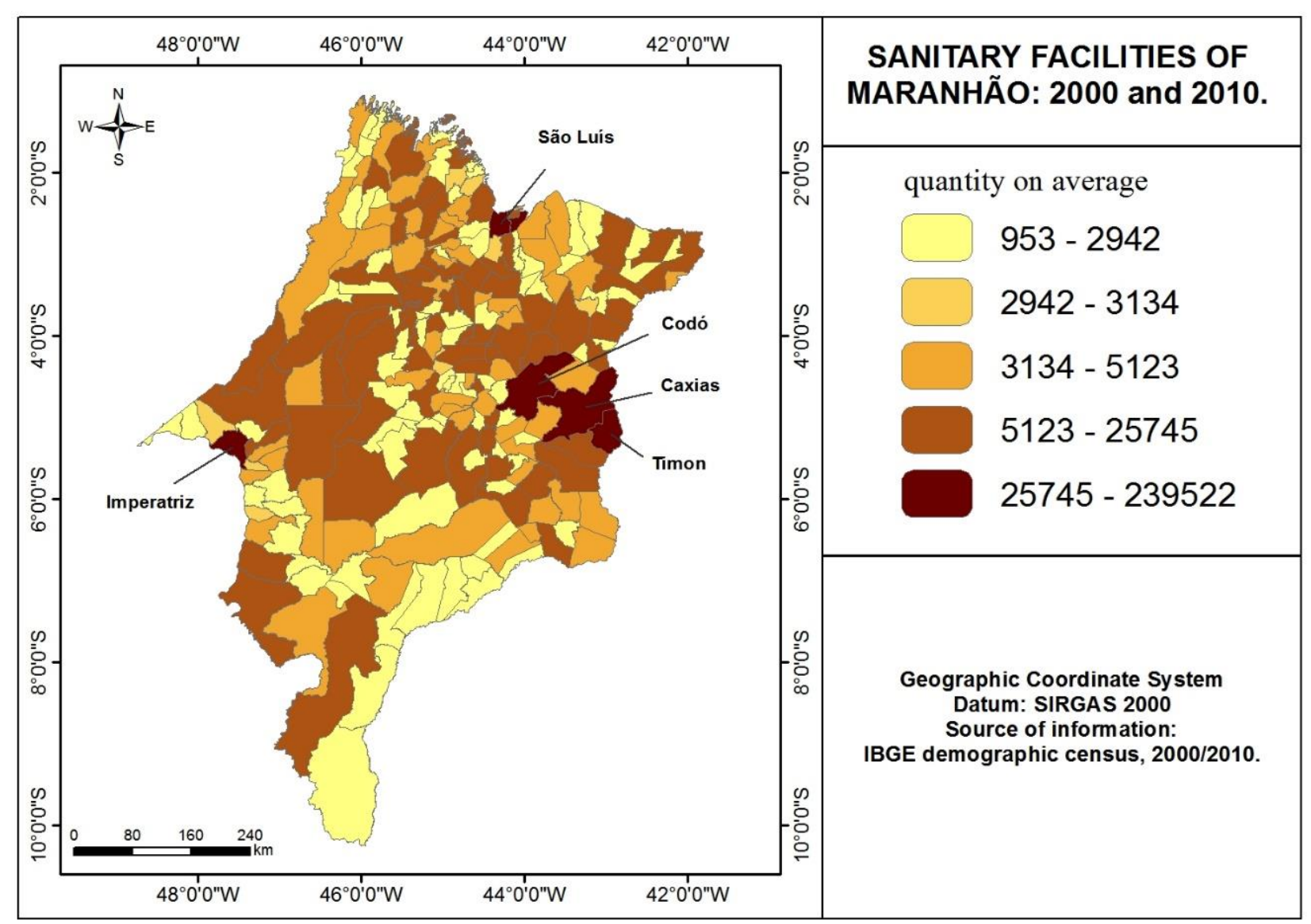

Figure 1. Map of distribution of sanitary facilities in State of Maranhão. Data from IBGE (2000 e 2010). 


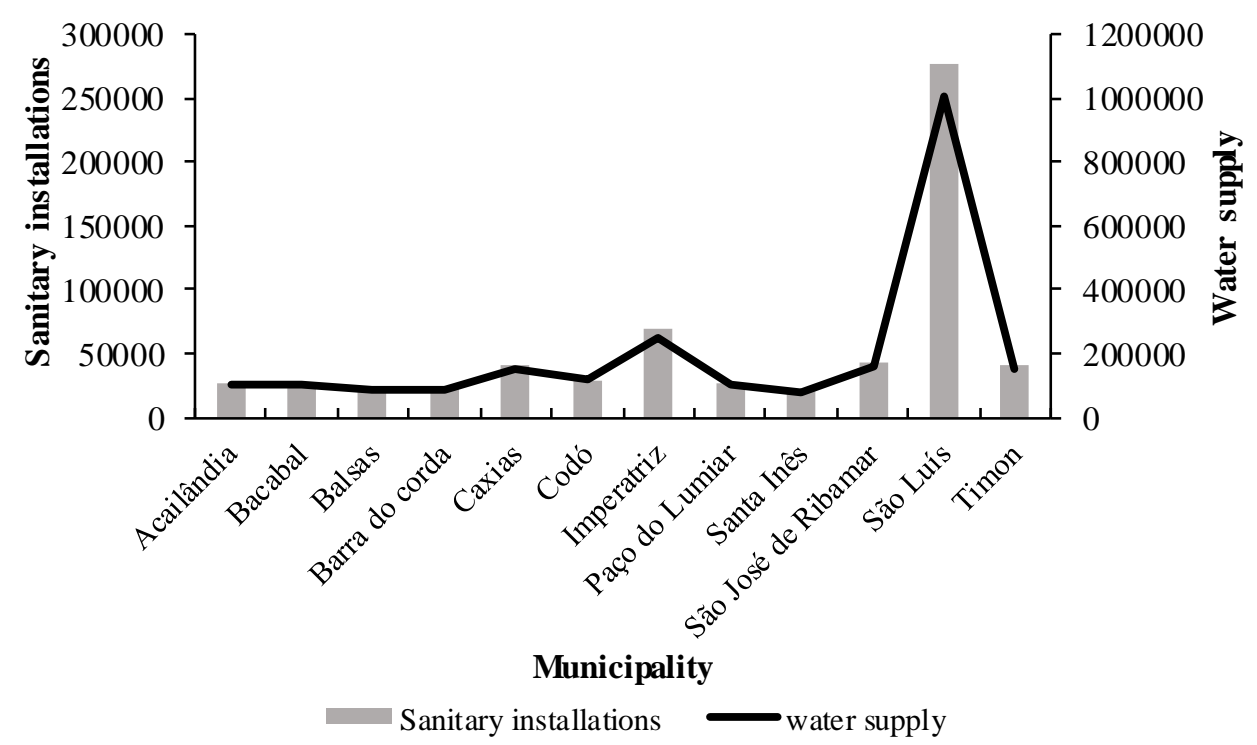

Figure 2. Municipalities with higher number of sanitary facilities and water supply according to the 2010 census.

The statistical analysis is presented in table 1. According to the Kolmogorov-Smirvov normality test at $0.01 \%$ probability, the data for the years 2000 and 2010 had a normal distribution. The also had a lognormal distribution, as evidenced by the high values in the asymmetry coefficients ( $C A=11,748$ ) and kurtosis (CK = 156,092). According to GOMES and GARCIA (2002), the CV value were considered high, with a value higher than 30\% (Table 1).

Table 1. Statistical parameters for the means of the demographic censuses carried out in 2000 and 2010.

\begin{tabular}{|c|c|c|c|c|c|c|c|c|c|c|}
\hline & $\mathrm{N}$ & Min & Max & Mean & Variance & $\begin{array}{l}\text { Standard } \\
\text { deviation }\end{array}$ & $\mathrm{CV}$ & Skew & Kurtosis & $\begin{array}{l}\text { Kolmogorov- } \\
\text { Smirnov stat }\end{array}$ \\
\hline 2000/2010* & 217 & 953 & 239521.500 & 6657.136 & $2.97 E+08$ & 17237.96 & 258.940 & 11.748 & 156.092 & $0.370 \mathrm{Ln}$ \\
\hline
\end{tabular}

*N: number of values; Average of 2000 and 2010; Min: Minimum; Max: Maximum; CV: Coefficient of variation.

Table 2. Matrix of linear correlation for the counties with higher number of sanitary facilities in the census of 2010.

\begin{tabular}{cccccc}
\hline & Sanitary Facilities & Water Supply & Garbage collect & Mortality & GDP per capita \\
\hline Sanitary Facilities & 1.000 & & & & \\
Water Supply & 1.000 & 1.000 & & & \\
Garbage collect & 0.994 & 0.994 & 1.000 & & \\
Mortality & 0.998 & 0.998 & 0.992 & 1.000 & 0.629 \\
GDP per capita * & 0.615 & 0.611 & 0.625 & 1.000 \\
\hline
\end{tabular}

* Gross Domestic Product divided by the number of inhabitants of the municipality.

The table 2 shows the matrix of linear correlation for the 12 counties with the highest amount of sanitary facilities.
According to the classification of Santos (2007), all the data had positive correlation, and high dependence. The highest correlation 
was observed between the quantity of sanitary facilities and water supply $(r=1,000)$, in this case, it can be stated that the quantity of sanitary facilities per county is directly related to water supply, that is, municipalities with higher water supply have more facilities (Figure 2).

The correlations between sanitary facilities and garbage collection ( $r=0.994)$; Facilities and mortality ( $r=0.998)$; facilities and GDP per capita $(r=0.615)$ were also high (Table 2$)$. These correlations show a direct relationship between the number of facilities and the parameters evaluated. Thus, it is expected that the higher the GDP per capita, the more appropriate the disposal of fecal waste. With this the population became less susceptible to health problems related to sewage.

According to data from the National Survey by household sampling of the Brazilian Institute of Geography and Statistics (PnadIBGE), in 2010, Brazil had 95\% of the households with access to water, however, $56 \%$ had access to adequate sewage.

\section{CONCLUSIONS}

The situation of sanitary sewage in the state of Maranhão is serious. Since few counties have a reasonable number of sanitary facilities. The data showed that only the capital São Luís has more sanitary facilities and more households with water supply. The correlations between the number of facilities with other variables, such as water supply, garbage collection, mortality and per capita GDP was high. In general, the data revealed a concerning situation for the State of Maranhão, which points out to a greater demand on public health issues in this state. 
OMS - Organização Mundial da Sáude. 2008. 5 steps for planning and evaluating world water day activities. World Health Organization.

OMS - Organização Mundial da Sáude. 2009. Global health risks - mortality and burden of disease attributable to selected major risks. World Health Organization.

Saucha, C.V.V.; Silva, J.A.M.; Amorim, L.B. 2015. Condições de saneamento básico em áreas hiperendêmicas para esquistossomose no Estado de Pernambuco em 2012. Epidemiol. Serv. Saúde, Brasília, 24(3):497506.

Scriptore, J.S.; Júnior, R.T. 2012. A estrutura de provisão dos serviços de saneamento básico no Brasil: uma análise comparativa do desempenho dos provedores públicos e privados. Rev. Adm. Pública - Rio de Janeiro 46(6):1479-1504.

Silva, M.T.N.; Souza, V.M.; Bragagnoli, G.; Pereira, T.G.R.; Malagueño, E. 2010. Atopic dermatitis and ascariasis in children aged 2 to 10 years. J Pediatr (Rio J). 86(1):53-58. 